\title{
Development Index of Village
}

\author{
Roziana Ainul Hidayati \\ University Of Muhammadiyah Gresik, Indonesia \\ E-mail: roziana.umg@gmail.com
}

Received: July 29, 2019 Accepted: September 10, 2019 Published: September 13, 2019

doi: 10.5296/jsss.v7i1.15349 URL: https://doi.org/10.5296/jsss.v7i1.15349

\begin{abstract}
Development Index of Village (IPD) is part of a development plan Rural Development Information System (SIPDs) and Rural Area Development is based on Law No. 6 of 2014 on the village of Article 86, which is one of its verses says "Government and Local Government shall develop an information system of the village and the Development of rural areas". Development Index of Village (IPD) was built by the Village Potential Census data (Podes) issued by the Central Statistics Agency (BPS) conducted within a period of 3 (three) years. There are five (5) dimensions of rural development index (IPD) is the first basic service, the condition of infrastructure, third-accessibility / transport, public services fourth, and fifth Implementation of government. IPD village classifies into Villages, Village Developing and Village Self. Based on the research results Hidayati (2015) obtained the data that the proportion of the population living below the national poverty line in Tuban regency suffered progress backwards with PHI value of -0.293 , the ratio of depth of poverty in the district Tuban also retreated with PHI value of - 0.141. Similarly, the ratio of employment to population aged 15 years and over in Tuban experiencing progress backwards with PHI value of - 0.063. While Indicator of education in almost all districts in Tuban, many have not reached the target or targets were heading except for indicators dropout rate (DO) of children aged 7-15 years (2.2.z), figure Attrition SD (2.f) and figure Dropout SMP (2.g). These facts are an indication that the achievement of development in Tuban Regency still needs a big effort to be improved. Therefore, in order to improve the development strategy in Tuban regency proper and appropriate program / target location, it is necessary to conduct a study to first identify the achievement of Village Development Index in each Village and District based on 5 Dimension of IPD and conducted Clusterization of Village Development per District in Tuban Regency based IPD (Podes 2014). In order to achieve these objectives are used IPD scorecard and IPD maping techniques. And the result is the majority in almost all districts in Tuban Regency IPD performance related to the dimensions of economic infrastructure, communication infrastructure and information and public services in the field
\end{abstract}


of sports is still far from the target Minimum Service Standards Tuban. IPD achievements are related to the dimensions of energy infrastructure, health and sanitation infrastructure and transportation accessibility, public service in the field of public health and self-reliance in governance shows that almost all districts in Tuban Regency have reached the Minimum Service Standards target. The dimension of governance is a dimension whose level of development achievement does not have a red scorecard for all sub-districts. The village with the highest IPD achievement in Tuban Regency is Sukosari Village, Soko District whereas the lowest IPD achievement is Ngrejeng village, Grabagan sub-district. The percentage of classification of village status in Tuban Regency covers $2.57 \%$ of the villages, $90.68 \%$ for developing villages and independent villages as much as $6.75 \%$. Based on Cluster Mapping of Village Development Index, Grabagan District is a sub-district with the Lowest Village Development Index level, especially in terms of its infrastructure development dimension. Next Kerek District and District Kenduruan as the second lowest cluster. While the District Jatirogo, Bancar, Tambakboyo, Bangilan, Senori, Parengan, Soko and Semanding. As a sub-district with the highest cluster that has a Village Development Index above 64.09 is District Jenu, Merakurak, Tuban, Cross, Widang, Plumpang, Rengel, Montong and Singgahan

Keywords: Development Index of Village, IPD scorecard, IPD maping

\section{Introduction}

The Village Development Index (IPD) is part of the plan to develop a Village Development Information System (SIPD) and Development Rural Area which is based on Law No. 6 of 2014 concerning Villages article 86, which in one paragraph states "The Government and Regional Governments are obliged to develop a village information system and development of rural areas." The Village Development Index (IPD) is built based on the Village Potential (Podes) census data issued by the Central Statistics Agency (BPS) conducted in a period of 3 (three) years. There are 5 (five) dimensions of the village development index (IPD), namely the first basic services, both infrastructure conditions, thirdly accessibility / transportation, the fourth public service, and the fifth administration. And based on the results of Hidayati's research (2015), it was obtained data that the proportion of people living below the national poverty line in Tuban district experienced a backward progress with a PHI value of -0.293 , the Depth of poverty ratio in Tuban district whose progress also retreated with a PHI value of - 0.141. Likewise, the employment opportunity ratio for residents aged 15 years and over in Tuban Regency has a backward progress with a PHI value of -0.063 . While many education indicators in almost all sub-districts in Tuban District have not reached the target or are heading towards targets except for indicators of dropout rates (DO) for children aged 7-15 years (2.2.z), drop-out rates for elementary school (2.f), and drop out rates for junior high school (2.g)

The problem in rural development is the low assets controlled by rural communities coupled with the still low access of rural communities to economic resources such as land / land, capital, production inputs, skills and technology, information, as well as cooperation networks. Other positions, the low level of services in rural infrastructure and facilities and the low quality of human resources in rural areas which are mostlylow skilled, weak institutions and community-based organizations, weak cross-sector coordination in rural area development. 
Therefore, it can be seen some of the objectives that can be done in village development as follows:

1). Improve services in terms of land and process land issues within the boundaries of the authority of the Regency.

2). Strengthening the management of space utilization and controlling the use of space to create an efficient, effective and sustainable living environment

$3)$. Improving the quality of safe, comfortable and healthy settlements.

4). Increased regional infrastructure in disadvantaged, remote and border areas.

5). Improve the quality of development planning in regions and regions.

6). Increasing the regional economy for the welfare of the community and overcoming disparities between regions.

7). Rural Development.

However, the most important targets to be achieved in Village Development are:

1). Realizing the welfare of rural communities.

2). Increased quality and quantity of infrastructure in residential areas in rural areas.

3). Increased access, control and participation of all elements of society.

Rural development policies in 2010-2014 are directed at increasing the welfare and quality of life of rural communities with the following steps:

1). Expanding public access to productive resources for business development such as land, socio-economic infrastructure, capital, information, technology and innovation, and public access to public services and markets.

2). Increasing the empowerment of rural communities through improving their quality, and strengthening institutions and social capital in rural communities in the form of cooperative networks to strengthen their bargaining position.

3). Improve the welfare of rural communities by fulfilling basic rights.

4). The creation of quality employment in rural areas, especially non-government employment.

IPD is a measure prepared to assess the level of progress or development of a village in Indonesia with its unit of analysis "Village. On the basis of the mandate, the Village is classified based on the IPD into Independent Village, Developing Village and Disadvantaged Village. The Village Development Index (IPD) is structured to see the level of village development in Indonesia. In addition, the IPD is intended as an instrument: (a) village development planning in Indonesia; (b) monitoring and evaluating village development performance; and (c) measurement of achievement of the national development target for 2015-2019 in Indonesia. IPD is expected to provide a number of benefits. First, IPD contains important data and information that can be used as a reference / reference to see the condition and level of village development in Indonesia in the current position. This data greatly helps policy makers at the central and regional levels, observers, researchers, students, and even the villagers themselves to understand the latest conditions in the progress of rural development in Indonesia. Second, IPD is useful as an ingredient for village development planning at the central level (Ministries / Institutions), provincial level (Bappeda and SKPD related to village 
development), district / city level (Bappeda and SKPD related to village development), and village level (village government and villagers). IPD contains data that can show which dimensions, variables, and indicators need to be supported to be improved and which do not need to be supported because they are considered to be optimal / adequate at the village level. All village development stakeholders can make the IPD a reference in the process of policy formulation, preparation, implementation, monitoring and evaluation of village development programs. Third, IPD is useful for monitoring and evaluating the implementation of programs in village development, conformity between programs that have been implemented with village needs, and achieving improved status of the progress of the village.

Therefore, in order to determine strategies to increase development in Tuban District to reduce poverty there is a need to do first the identification of the village development index in Tuban Regency which is felt to be weak from the five dimensions stipulated in the IPD and it should also be mapped which ones fall into the category of underdeveloped, developing and independent villages so that later in establishing development strategies in the Regency Tuban will be right on target, the right program and the right location.

\section{Methodology}

This type of research is a type of descriptive research. The data collection techniques used in this study are as follows primary data collection, namely data collection conducted in the field to support analysis of the results of secondary data extension. Primary data collection is done by interview. The interviews were carried out on key informants in order to obtain information related to the results of secondary data processing which would later be used to form appropriate rural development programs in Tuban Regency. The key informant in question is a staff planning planner in the village of Tuban. Secondary data collection; obtained from 2014 village potential data from BPS. The population of this study is the Village Potential Data which includes 5 dimensions. While the sample in this study is the data of the Village Potential Data of Tuban Regency in 2014 which covers 311 villages. In analyzing the data in this study, the analytical techniques are used as follows:

A). IPD technique IPD Scorecard to analyze the achievement of village and sub-district levelin Tuban Regency based on 5 dimensions. This card is symbolized in three colors, namely:

1). Red indicates development is still "far from the direction of achievement.

2). The yellow color indicates "in the direction of achievement" / on track;

3). Green indicates "has reached the target.

B). IPD mapping is used to cluster village development per sub-district in Tuban Regency based on 5 dimensions

\section{Result and Discussion}

Achievement Index Rural Development (IPD) Tuban at the village level and the District based on the 5 Dimensions (Podes 2014). Achievement Index Rural Development (IPD) Tuban at district level based on the 5 Dimensions of IPD (Podes 2014) using techniques IPD scorecard, the result as The following: 
Table 1. Achievement of the Village Development Index (IPD) at the District Level of Tuban District

\begin{tabular}{|c|c|c|c|c|c|c|c|c|c|c|c|c|c|c|c|c|c|c|c|c|c|c|}
\hline Dimensi & Variabel & KENDURAN & DANGILAN & SENORI & $\underset{\text { AN }}{\text { IINGAH }}$ & MONTONG & PARCNGAN & sоко & RENGLL & $\underset{\substack{\text { GRABA- } \\
\text { GAN }}}{-}$ & \begin{tabular}{|l|} 
PLUM- \\
PANG
\end{tabular} & WIDANG & PALANG & $\begin{array}{c}\text { SEMAN- } \\
\text { DING }\end{array}$ & TUBAN & JeNU & $\begin{array}{l}\text { MERAK- } \\
\text { URAK }\end{array}$ & KCRCK & \begin{tabular}{|c|} 
TEMBAK \\
BOYO
\end{tabular} & \begin{tabular}{|c|} 
JATT- \\
ROGO
\end{tabular} & DANCAR & $\begin{array}{l}\text { Kab. } \\
\text { Tuban }\end{array}$ \\
\hline \multicolumn{2}{|c|}{ Pelayanan Dasar } & 3.01 & 3.15 & 3.42 & 3.32 & 3.08 & 3.21 & 3.31 & 3.31 & 2.98 & 3.21 & 3.41 & 3.44 & 3.32 & 3.44 & 3.22 & 3.53 & 2.52 & 2.94 & 2.92 & 3.04 & 3.20 \\
\hline & Pelsyanan Penclidilan & 3.22 & 3.39 & 3.65 & 3.56 & 3.40 & 3.21 & 3.27 & 3.25 & 3.02 & 3.17 & 3.59 & 3.25 & 3.13 & 3.33 & 3.09 & 3.46 & 2.60 & 3.19 & 3.14 & 3.34 & 3.26 \\
\hline & Palryanan Keschovan & 2.90 & 3.03 & 3.31 & 3.20 & 2.92 & 3.22 & 3.33 & 3.34 & 2.97 & 3.23 & 3.31 & 3.53 & 3.42 & 3.50 & 3.28 & 3.57 & 2.49 & 2.82 & 2.81 & 2.89 & 3.15 \\
\hline \multicolumn{2}{|c|}{ Kondisi Infrastruktur } & 2.40 & 2.85 & 2.65 & 2.88 & 2.33 & 2.39 & 2.49 & 2.88 & 1.92 & 3.01 & 2.86 & 3.07 & 2.68 & 2.74 & 3.04 & 2.70 & 2.28 & 2.84 & 2.68 & 2.60 & 2.67 \\
\hline & Infrastruktur tkonami & 0.69 & 0.89 & 0.65 & 1.18 & 0.88 & 0.93 & 0.72 & 1.03 & 0.44 & 0.89 & 1.18 & 1.32 & 0.87 & 1.07 & 1.15 & 0.93 & 0.54 & 1.14 & 1.02 & 1.33 & 0.94 \\
\hline & Infrastruktur Lnergi & 4.33 & 4.88 & 4.56 & 4.94 & 4.23 & 4.33 & 4.68 & 4.71 & 3.55 & 5.00 & 4.71 & 5.00 & 4.27 & 4.33 & 4.92 & 4.56 & 3.20 & 4.91 & 4.56 & 4.24 & 4.49 \\
\hline & 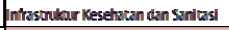 & 3.48 & 4.07 & 3.97 & 3.94 & 3.31 & 3.11 & 3.48 & 4.27 & 3.03 & 4.63 & 4.23 & 4.46 & 4.40 & 3.67 & 4.57 & 4.02 & 4.43 & 3.74 & 4.06 & 3.36 & 3.91 \\
\hline & 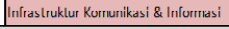 & 2.17 & 2.86 & 2.79 & 2.42 & 1.62 & 2.06 & 2.15 & 2.69 & 1.55 & 2.89 & 2.25 & 2.44 & 2.23 & 3.17 & 2.62 & 2.39 & 2.03 & 2.64 & 1.92 & 2.19 & 2.35 \\
\hline \multicolumn{2}{|c|}{ Aksesibilitas/Transportasi } & 3.93 & 3.94 & 3.55 & 4.29 & 4.47 & 4.10 & 4.09 & 4.23 & 3.27 & 4.01 & 4.15 & 3.88 & 3.52 & 3.25 & 4.15 & 3.92 & 4.43 & 4.26 & 4.28 & 4.20 & 3.98 \\
\hline & Serana Transporcasl & 3.08 & 3.63 & 3.13 & 3.96 & 4.46 & 3.53 & 3.55 & 3.98 & 3.39 & 3.69 & 3.69 & 3.64 & 3.35 & 3.17 & 4.06 & 3.62 & 4.46 & 3.94 & 4.01 & 3.64 & 3.70 \\
\hline & Alsesitiflias Tramspartasi & 4.78 & 4.25 & 3.98 & 4.63 & 4.48 & 4.67 & 4.62 & 4.47 & 3.16 & 4.33 & 4.61 & 4.13 & 3.68 & 3.33 & 4.25 & 4.22 & 4.40 & 4.57 & 4.54 & 4.76 & 4.29 \\
\hline \multicolumn{2}{|c|}{ Pelay anan Publik } & 2.92 & 3.13 & 3.23 & 3.25 & 3.79 & 3.18 & 3.48 & 3.41 & 2.75 & 3.32 & 3.23 & 3.08 & 3.02 & 3.67 & 2.88 & 2.99 & 2.41 & 3.00 & 2.93 & 2.83 & 3.14 \\
\hline & Kesehatan Masyarakat & 4.44 & 4.71 & 4.58 & 4.67 & 4.92 & 4.53 & 4.96 & 4.50 & 4.27 & 4.94 & 4.75 & 5.00 & 4.40 & 5.00 & 4.41 & 4.53 & 3.97 & 4.89 & 4.61 & 4.31 & 4.62 \\
\hline & Olah Raga & 1.39 & 1.54 & 1.88 & 1.83 & 2.65 & 1.83 & 2.00 & 2.31 & 1.23 & 1.69 & 1.72 & 1.17 & 1.63 & 2.33 & 1.35 & 1.45 & 0.85 & 1.11 & 1.25 & 1.35 & 1.63 \\
\hline \multicolumn{2}{|c|}{ Penyelenggaraan Pemerintahan } & 3.22 & 3.41 & 3.62 & 3.85 & 3.51 & 3.54 & 3.78 & 4.09 & 3.38 & 4.37 & 4.01 & 3.98 & 3.81 & 4.53 & 3.64 & 3.69 & 3.53 & 3.79 & 3.60 & 3.43 & 3.76 \\
\hline & Kemsndinan & 3.19 & 3.83 & 3.89 & 4.22 & 3.87 & 3.93 & 4.06 & 4.65 & 3.64 & 4.54 & 4.50 & 4.17 & 3.76 & 4.67 & 4.02 & 3.84 & 3.69 & 4.28 & 4.06 & 3.51 & 4.01 \\
\hline & Kusliturs SOM & 3.28 & 2.79 & 3.21 & 3.29 & 2.96 & 2.97 & 3.37 & 3.25 & 3.00 & 4.11 & 3.28 & 3.69 & 3.90 & 4.33 & 3.06 & 3.47 & 3.29 & 3.06 & 2.92 & 3.29 & 3.33 \\
\hline
\end{tabular}

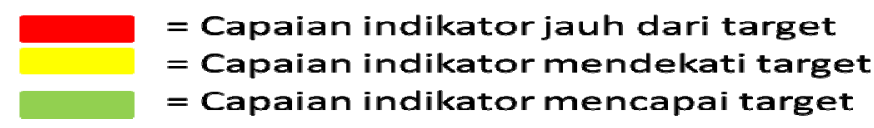

Source: data processed.

Based on Table 1 above shows that in Tuban Regency is related to economic infrastructure, communication and information infrastructure and public services in the majority of sports in almost all the sub-district achievement is still far from the target of the Minimum Service Standard of Tuban Regency.

Whereas village development related to energy infrastructure, health infrastructure and sanitation and accessibility of transportation, public services in the field of public health and marriages in the administration of government shows that almost all sub-districts in Tuban Regency have reached the target of Minimum Service Standards. Especially in the field of administration of Tuban regency, the level of development achievements in none of the districts in Tuban has a red scorecard.

While the achievements of the Village Development Index for each village in each sub-district in Tuban Regency are based on 5 dimensions, namely the dimensions of Basic Services, Conditions of Infrastructure, Accessibility / Transportation, Public Services and Administration of Government in detail in the appendix.

Meanwhile from the village level Tuban Regency Development Index (IPD) ranking based on 5 dimensions of IPD (2014 Podes) which ranked highest in 2014 was Sukosari Village, Soko Subdistrict, while the lowest village development achievement was Ngrejeng village, Grabagan District with Development index Village of 2.12.

Tuban Regency itself, if seen from the percentage of village status classification as seen in Table 2, then $2.57 \%$ of those who are still underdeveloped villages, which are classified as developing villages are $90.68 \%$ and those that have entered the independent village category are $6.75 \%$. When compared with other regencies in East Java which belong to the independent village group, they are still relatively small. 
Table 2. Percentage of Village Classification in Tuban District

\begin{tabular}{|c|c|c|c|c|c|c|c|c|c|c|}
\hline \multirow{2}{*}{$\begin{array}{c}\text { Nams } \\
\text { Kabupaten/Kota }\end{array}$} & \multirow{2}{*}{ WD 2014} & \multirow{2}{*}{$\begin{array}{l}\text { Petayanan } \\
\text { Dasar }\end{array}$} & \multirow{2}{*}{$\begin{array}{l}\text { Kondast } \\
\text { intrastructur }\end{array}$} & \multirow{2}{*}{ Akcesibutas/ } & \multirow{2}{*}{ Pelayanan } & \multirow{2}{*}{ Peayelengaraan } & \multicolumn{3}{|c|}{ Persentuse Klasimanas Besa } & \multirow{2}{*}{ Jumbah } \\
\hline & & & & & & & Terunuzat & $\begin{array}{l}\text { Herkan-1 } \\
\text { hang }\end{array}$ & Mandiri & \\
\hline Pacitan & 64,16 & 66,41 & 44,88 & 82,86 & 57.82 & 73,50 & 0.00 & 95,78 & 4.22 & 166 \\
\hline Ponorogo & 65,07 & 68,11 & 50,13 & 76,53 & 53,86 & 80,40 & 1,42 & 89,68 & 8,90 & 281 \\
\hline Trenggalek & 64,07 & 67,83 & 45,43 & 78,04 & 55,22 & 78,72 & 3,95 & 84,21 & 11,84 & 152 \\
\hline Tulungagung & 65,74 & 69,47 & 53,38 & 71,67 & 58,48 & 79,36 & 1,56 & 86,77 & 11,67 & 257 \\
\hline Blitar & 65,21 & 68,69 & 51,00 & 73.72 & 60.27 & 76,72 & 0.45 & 92,73 & 6,82 & 220 \\
\hline Kediri & 65,86 & 70,13 & 55.35 & 73,13 & 55,05 & 74,60 & 0.58 & 88,63 & 10,79 & 343 \\
\hline Malang & 66,61 & 69,15 & 52,18 & 81,69 & 56,37 & 74,52 & 1,86 & 81,96 & 16,18 & 377 \\
\hline Lumajang & 61,45 & 66,37 & 46,89 & 72,53 & 52,64 & 68,53 & 5,05 & 91,92 & 3,03 & 198 \\
\hline Jember & 66.73 & 73.74 & 50,11 & 74,90 & 58,86 & 76.87 & 0,44 & 88,05 & 11,50 & 226 \\
\hline Banyuwangi & 69,70 & 73,50 & 56,44 & 79,39 & 62,06 & 78,55 & 0,00 & 77,25 & 22,75 & 189 \\
\hline Bondowoso & 59,54 & 68,18 & 40,37 & 72,78 & 46,38 & 66,46 & 8,13 & 90,43 & 1,44 & 209 \\
\hline Situbondo & 61,98 & 67,79 & 48,03 & 74,79 & 47,12 & 67,79 & 9,09 & 82,58 & 8,33 & 132 \\
\hline Probolinggo & 63,80 & 68,82 & 46,51 & 79,97 & 47,82 & 74.59 & 2,77 & 89.85 & 7,38 & 325 \\
\hline Pasuruan & 63,54 & 67,43 & 50,41 & 80,35 & 52,32 & 62,13 & 3,52 & 88,27 & 8,21 & 341 \\
\hline Sidoarjo & 67,97 & 73,10 & 57,72 & 75,09 & 55,76 & 75,26 & 0,31 & 81,99 & 17,70 & 322 \\
\hline Mojokerto & 65,90 & 70,08 & 55,66 & 71,94 & 51,89 & 79,84 & 0,67 & 89,63 & 9,70 & 299 \\
\hline Jombang & 66,14 & 71,45 & 55,52 & 74.72 & 51.73 & 73,28 & 0.33 & 89,07 & 10,60 & 302 \\
\hline Nganjuk & 65,18 & 68,90 & 54,34 & 73,95 & 49,73 & 78,20 & 2,65 & 90,15 & 7,20 & 264 \\
\hline Madiun & 67,34 & 70,49 & 55,69 & 75,94 & 57,94 & 78,29 & 1,01 & 87,88 & 11,11 & 198 \\
\hline Magetan & 66,99 & 70,88 & 54,17 & 77,91 & 54,43 & 77,23 & 0,00 & 92,27 & 7,73 & 207 \\
\hline Ngawi & 64,98 & 68,97 & 52,96 & 69.84 & 56,87 & 79,86 & 0.94 & 86,85 & 12,21 & 213 \\
\hline Bojonegoro & 65,54 & 65,14 & 54.30 & 78,49 & 55,79 & 78,34 & 0.95 & 90.93 & 8,11 & 419 \\
\hline Tuban & 63,33 & 63,02 & 53.91 & 74,65 & 54,09 & 74,19 & 2,57 & 90,68 & 6,75 & 311 \\
\hline Lamongan & 65,30 & 70,45 & 53,17 & 72,04 & 53,89 & 76,80 & 0,43 & 90,69 & 8,87 & 462 \\
\hline Gresik & 65,94 & 69,78 & 55,86 & 74,08 & 55,67 & 72,83 & 0.00 & 87.58 & 12,42 & 330 \\
\hline Bangkcalan & 56,84 & 61,84 & 45,71 & 76,39 & 43,08 & 44,87 & 16,12 & 83,52 & 0,37 & 273 \\
\hline Sampang & 59,57 & 67,14 & 43,00 & 80,58 & 46,01 & 49,54 & 7.78 & 91,11 & 1,11 & 180 \\
\hline Pamekasan & 61,71 & 69,07 & 49,15 & 77,44 & 45,35 & 55,75 & 3,93 & 94,38 & 1,69 & 178 \\
\hline Sumenep & 60,34 & 63.24 & 44,00 & 77.20 & 48,55 & 69.77 & 8.79 & 88,48 & 2,73 & 330 \\
\hline Batu & 72,51 & 74,45 & 58,02 & 87,86 & 60,52 & 83,56 & 0,00 & 68,42 & 31,58 & 19 \\
\hline lawa Timur & 64,54 & 68,55 & 51.45 & 75,92 & 53,36 & 72,80 & 2.69 & 88,33 & 8,97 & 7.723 \\
\hline
\end{tabular}

Source: www.Bappenas.go.od/2014.

Village Development Clustering per District in Tuban Regency based on IPD (2014 Podes)

Klasterisasi Tingkat Perkembangan Desa (4 Klaster) per kecamatan di Kab. Tuban berdasarkan IPD (Podes 2014)

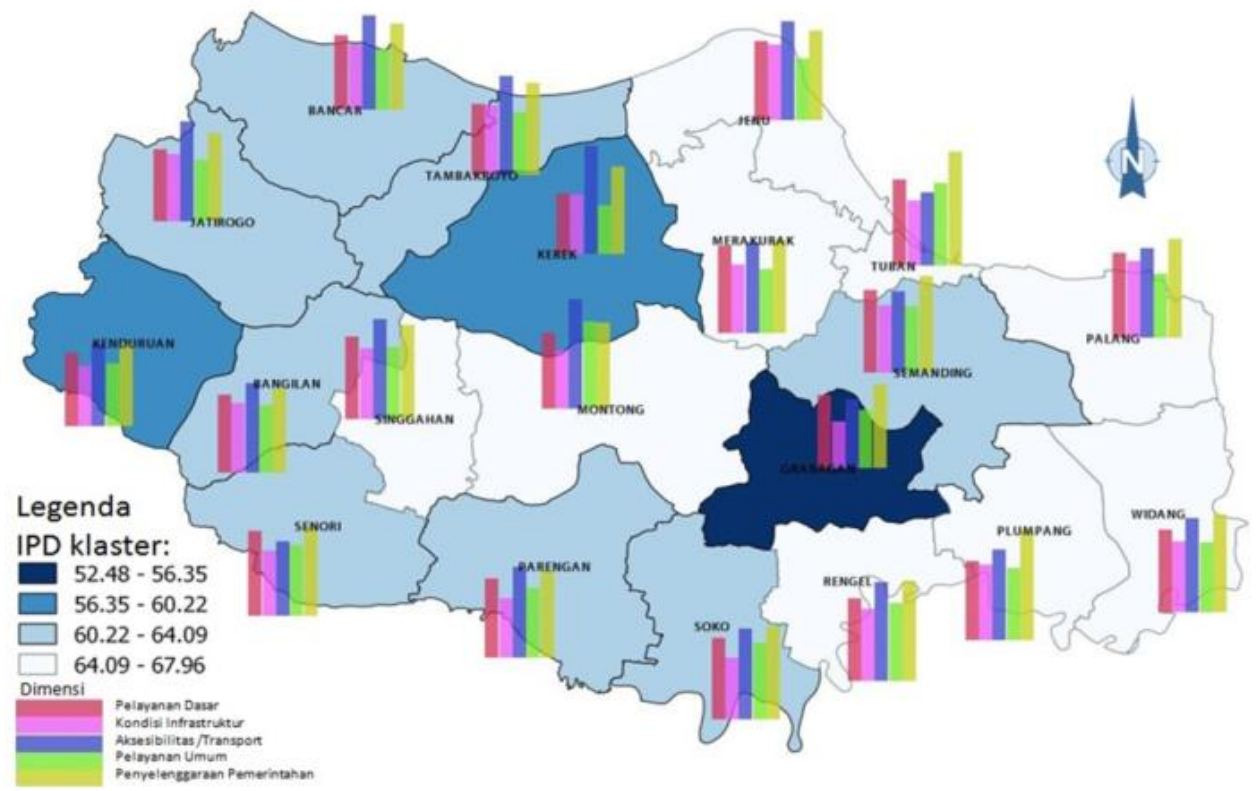

Figure 1. Clustering of Village Development Index per District in Tuban District 
When viewed from the mapping of the Village Development Index above, it can be seen that Grabagan Subdistrict is a sub-district with the lowest Village Development Index in terms of the dimensions of infrastructure development. Subsequently followed by Kerek District and Kenduruan District as the second lowest cluster. Whereas Jatirogo, Bancar, Tambakboyo, Bangilan, Senori, Parengan, Soko and Semanding Subdistricts. As the sub-district with the highest cluster, which has a Village Development Index above 64.09, the Districts are Jenu, Merakurak, Tuban, Palang, Widang, Plumpang, Rengel, Montong and Singgahan.

Interestingly in general, almost all sub-districts in Tuban Regency, the level of Government Administration and Transport Accessibility is quite good. Whereas the condition of infrastructure in almost all sub-districts is still quite low.

\section{Conclusions and Recommendation}

\subsection{Conclusions}

1). The majority in almost all sub-districts in Tuban District, the achievement of the Village Development Index related to the dimensions of economic infrastructure, communication and information infrastructure and public services in sports is still far from the target of the Minimum Service Standards in Tuban Regency.

2). The achievement of the village development index related to the dimensions of energy infrastructure, health infrastructure and sanitation and accessibility of transportation, public services in the field of public health and the ministry in administering government shows that almost all sub-districts in Tuban Regency have reached the target of Minimum Service Standards.

3). The dimensions of governance are a dimension where none of the development achievement levels has a red scorecard for all sub-districts in Tuban Regency.

4). The village with the highest Village Development Index (IPD) in Tuban Regency is Sukosari Village, Soko Subdistrict, while the lowest achievement of the Village Development Index is Ngrejeng Village, Grabagan Subdistrict

5). Percentage of village status classification in Tuban Regency covers 2.57 rural categories \%, villages develop $90.68 \%$ and independent villages as much as $6.75 \%$.

6). Based on the Mapping of Village Development Index Cluster, Grabagan District is a sub-district with the lowest level of Village Development Index, especially in terms of the dimensions of infrastructure development. Subsequently followed by Kerek District and Kenduruan District as the second lowest cluster. While Jatirogo, Bancar, Tambakboyo, Bangilan, Senori, Parengan, Soko and Semanding Districts. As the sub-district with the highest cluster, which has a Village Development Index above 64.09, the Districts are Jenu, Merakurak, Tuban, Palang, Widang, Plumpang, Rengel, Montong and Singgahan.

\subsection{Recommendations}

1). Economic infrastructure in Tuban Regency should be improved by building cooperation with industries in Tuban Regency such as PT. Semen Indonesia through a CSR program

2). Its Communication and Information Infrastructure is maximized by encouraging investors in the field of communication and information to enter in Tuban Regency to provide their convenience in investing or by cooperating with PT. Telkom 
3). The government further increases public services in the field of sports by providing various sports facilities or by holding various sports activities.

4). Infrastructure Development in Tuban Regency should be of particular concern to the Tuban District Government considering that the Infrastructure dimension in almost all sub-districts in Tuban District has not yet reached the target of minimum service standards. This can be done by cooperating with industries in Tuban through a CSR program, increasing regional budget revenues through taxes and other sources of regional budgets.

\section{References}

Ahmadi, A., \& Uhbiyati, N. (2001). Educational Sciences. Jakarta: Rineka Cipta.

Ahmadi, A., \& Uhbiyati, N. (2001). Educational science. Jakarta: Rineka Cipta. Surakarta Regional Information and Development Center (PIPW) - UNS LPPM

National Development Planning Agency (Bappenas). (2001). Regional Development Index. Draft / Design in Summary Form. Jakarta:Bappenas

Tuban Central Bureau of Statistics (BPS). (2015). in Number Districts in Tuban District 2014.

Hidayati, R. A. (2015). Analysis of Measurements of Achievement of Poverty and Hunger Management in Tuban District Using Poverty and Hunger Index.

Kartasasmita, G. (2001). Development For the People: Integrating Growth and Equity, Jakarta: CIDESINDO Library.

Muhadjir, N. (2002). Qualitative Research Methodology (6th ed.), Publisher Raka Sarasin, Jogjakarta.

Mulyanto, Indicators and Characteristics of Village Development as the Basis of Implementation of the Village Law, Faculty of Economics and Business - Sebelas Maret University (UNS).

Government Regulation Number 43 of 2014 concerning Implementation Regulations Number 6 of 2014 concerning Villages (Gazette Republic of Indonesia Year 2014 Number 123, Supplement to the State Gazette of the Republic of Indonesia Number 5539).

Permendagri No. 66 of 2007 concerning Village Development Planning.

Satria, A. (2015). HereSome Definitions of Village Development According to Experts,http://www.materibelajar.id/2015/12/inilah-beberapa-definisi-pembangunan_28.html AreSuparno, A.Suhaenah. 2001. Building Learning Competencies. Directorate General of Higher Education: Ministry of National Education.

Law Number 6 Year 2014 concerning Villages (State Gazette of the Republic of Indonesia Year 2014 Number 7, Supplement to the State Gazette of the Republic of Indonesia Number 5495)

www.bappenas.go.id/index.php/download_file/view/17767/8888/

www.sapa .or.id / lp / 7748-system-Informasi-desa-000006 


\section{Copyright Disclaimer}

Copyright for this article is retained by the author(s), with first publication rights granted to the journal.

This is an open-access article distributed under the terms and conditions of the Creative Commons Attribution license (http://creativecommons.org/licenses/by/3.0/). 